\title{
Buddhism in Russia in XX century and environmental policy: government and legal regulation
}

\author{
Timur Badmatsyrenov ${ }^{1 *}$, Elizaveta Badmatsyrenova ${ }^{2}$, and Sanzhida Dansarunova ${ }^{1}$ \\ ${ }^{1}$ Buryat State University, Department of Sociology and Politology, 670000 Ulan-Ude, Russia \\ ${ }^{2}$ Buryat State University, Department of History and Theory of Law, 670000 Ulan-Ude, Russia
}

\begin{abstract}
The article is aimed at studying the modern model of relations between the Russian state and Buddhist communities. Today it is one of the most promising multidisciplinary endeavours of political, legal and sociological research. We have analyzed three models of interaction between the Russian state and Buddhist communities: the Imperial, the Soviet and the Contemporary. The article places special emphasis on the historical and legal analysis of the main stages in development of Russian legal policy in relation to Buddhism.
\end{abstract}

\section{Introduction}

Refuting the modernist thesis about the secularization of society, religion has an increasing influence on social processes in today's world. Modern nations find themselves in the situation of a "religious challenge", both in the form of pressure from the confessional groups in legal and informal field, and in the aspiration of states and elite groups to use the integrative legitimizing potential of religion. As a result, the interaction of public authorities with religious groups comes under constant correction at the level of constitutional provisions, sector specific legislation and judicial practice. Investigation concerning the development of a system for regulation of state-religious relations is one of the most promising areas of political and legal science.

During the late 1980s and 1990s, radical liberalization of the legislation on religion took place in Russia, fast growth of religiosity among population was observed, the confessional situation had been complicated by development of "non-traditional" religious trends, and institutions of the church, cult, and religious education were being transformed. In modern Russia, along with "traditionally" Buddhist Buryatia, Tyva and Kalmykia, new centers are emerging in major cities and new Buddhist communities of different schools with its specific structures and spread are being formed. In addition, "Global" Buddhism, the policy of the $14^{\text {th }}$ Dalai Lama and the Tibetan Diaspora has significant international impacts on socio-religious processes in Russia.

The article studies the specific features and development of a modern model of statereligious relations between the Russian state and Buddhism. In Russia there was several

\footnotetext{
* Corresponding author: batorovitch@mail.ru
} 
successive historical models of state-religious relations. The first, which took place in the Russian Empire, was characterized by the dominance of Orthodoxy as a state religion with limited rights for confession of other "admitted" beliefs. The second model, radically secular, had been formed during the Soviet period, when in certain periods state policy was aimed at deinstitutionalization of religion by political, legal and repressive measures. Today, the Russian state realizes a secular model, but, according to Zh. T. Toshchenko, it is "actively affected by the clerical processes" [1]. In addition, we should note the dynamism of these models, their susceptibility to frequent changes and correction of the current regulatory regimes, caused both by the transformation of the political system and the needs for improving the regulators of social relations in the sphere of religion.

\section{Stages of development of legal regulation}

We can identify several stages in the development of legal regulation of relations between the Russian state and Buddhist communities, which are characterized by the peripheral role of Buddhism in interactions with state institutions and the significant influence of changes in the Russian state policy on the development of Buddhist communities. Attention should also be given to the fact that the processes of formation of regional Buddhist communities and local systems of canonical Buddhist law were not completed by the time, when the territory of Kalmykia and Buryatia entered Russia, and, as a result, they experienced a significant impact of the Russian legal system.

The first stage was characterized by the development of the forms of state-religious relations and legal regulation of Buddhist communities. During the $17^{\text {th }}-19^{\text {th }}$ centuries the Russian Empire taking into account the diversity of ethnocultural and religious customs of the peoples of Russia had been legalizing them, and as a result the imperial law became a complex hierarchical system which included several procedural and regulatory regimes [2]. The confessional principle in development of the imperial political and legal system played a very important role, since the legal system was not based on individual civil rights and privileges, but on the group ones, primarily resident in a class or a confession. "The rulers of the Empire thought in confessional terms, not in ethnic, or any other categories, and confession was the ground of social order" [3]. This factor determined the great importance attached to the development of the relations between the imperial and provincial authorities and institutionalized Buddhist groups. That period was marked by a search for effective means to resolve the political and legal tasks of governing Buddhists, such as isolation of Russian Buddhists from the influence of foreign centers, which by the $17^{\text {th }}-18^{\text {th }}$ centuries were under the rule of the Qing Empire; provision of political and administrative control through the centralized church administration headed by Pandido Khambo lamas in Transbaikal and lamas of Volga Kalmyks in the regions where they lived. An optimal model of interaction between central and local authorities with Buryat and Kalmyk Buddhist communities had been developed over two centuries, it was reflected in the working out of a number of normative legal documents at the instance of both central and local provincial authorities by the middle of the $19^{\text {th }}$ century, since "the Buddhist community and the authorities came to the conviction that it is necessary to establish firm rules of their interaction" [3].

The Russian state with a view to expanding the foreign policy eastwards and ensuring control over the Transbaikalian territories entered in the $17^{\text {th }}$ century, which was inhabited by Buryats, provided significant support to the Buddhist sangha under the terms and conditions of administrative dependence on central and provincial authorities. That situation even had caused discontent of the Orthodox church administration. As a result, the peculiar Buddhist monastic organization was formed, characterized by a special hierarchy and regimen, a cultic, educational and parish system. The interaction of Buddhist 
monasteries with their parishes was carried out through local authorities in the Buryat uluses [4].

In the light of the situation, in 1853, after much work on development of an optimal model for regulation of the Buddhist communities with the participation of a number of departments, "Statute on the Lamaist clergy of Eastern Siberia" was adopted as a result of the formulation of the Eastern Siberia's Governor-General N. N. Muravyev and taking into account the proposals of several agencies [5]. It provided for significant regulatory restrictions on the activities of Buddhist clergy: centralization of the Buddhist communities' administration by the concentration of power in the hands of the Pandido Khambo lama, control over the supervising manpower of monasteries. Enrollment, appointment to the established posts, and elevation to the rank were carried out by the Khambo lama, but entered into force only after the approval of the tsarist administration and the issuance of the appropriate official diplomas [6].

For the official activities any lama had to have a diploma confirming his rank and appointment and certified by the provincial authorities, without which it was impossible to occupy the established positions in the monastery [7]. At the same time, thousands of lamas and khuvaraks, who lived in the monasteries of Transbaikal, took vows and initiations, got Buddhist education and ranks in Tibetan, Mongolian and Buryat monasteries beyond the establishment.

In 1917, a new stage of development of state-religious relations began. The first quarter of the $20^{\text {th }}$ century was the golden age for Buddhism of Buryatia, marked by active sociopolitical, ideological and regulatory activities of the Buryat national intelligentsia and Buddhist clergy. But along with the expansion of the network of monasteries, the growing number of clergy, the development of Buddhist culture and education, the struggle of various groups within the Buddhist clergy already existing at the end of the $19^{\text {th }}$ century had been intensified.

In 1918, a unique Buddhist Balagat theocratic state of L. S. Tsydenov had emerged in Buryatia, according to him "theocracy is a model of government, which imply that the head of a state is god who transmit orders and prohibitions to his priests; the rule of clergy, allegedly acting by the will of god; the state itself with such a system" [8]. Under the difficult conditions of the civil war and constant pressure from Ataman Semenov's authorities, as well as increasingly intensified contradictions among the Buryat social and political figures, Lubsan-Samdan Tsydenov developed and implemented a project of the theocratic republican state based on Buddhist ideas and headed by Yogachari Nomun Khan, Tsog Tuguldur Darmaranz (Yogi, King of Teaching, Magnificent and Perfect King of Dharma). The project of a theocratic state had demonstrated a religious-oriented political and legal model, which in many respects was close to the state formations of Bogd Gegeen and Neise Gegeen.

With the establishment of the Soviet state and the beginning of socialist transformations Buddhism became one of the main obstacles in construction of socialism.

One of the groups of the Buddhist clergy, "the renovationists", strove to reform the Buddhist faith and adapt Buddhist ideas to a new socialist order; they carried out a number of measures to develop a new legislation on Buddhism in Russia, which would provide for the introduction of collegiality and electivity in the governing system of monasteries, the expansion of laity participation, the abolition of exactions from believers [9]. However, mass repressions towards clergy, the physical extermination of thousands of monks during the campaign against religion in the country by the end of the 1930s result in a situation where the Buddhist community as an organization had virtually ceased to exist [6].

By the end of the Great Patriotic War, some provisions of Soviet religious policy had been revised, and consequently the restoration of religious organizations, as well as the opening of new religious buildings were permitted. The post-war organization of the 
Buddhist communities was based on strict control by the state and party, carried out in all Buddhist regions of the USSR. In accordance with "Regulations on the Buddhist clergy in the USSR," The Congress of clergy and laity representatives was declared the supreme body that formed the central executive board - The Central Buddhist Spiritual Authority of the USSR. Two monasteries were reopened - Ivolginsky in the Buryat-Mongolian ASSR and Aginsky in Chita Oblast.

\section{Modern system of state-religious relations}

After the collapse of the USSR and the establishment of the Russian Federation, a contemporary system of state-religious relations has emerged. The current Constitution of Russia and the constitutions (charters) of the subjects of the federation proclaim the secular state, guarantee the rights to freedom of religion and conscience. According to the current legislation, religious associations are equal before the law and separate from the State. Legislation regulating relations in the field of religion involves a number of provisions of the Constitution of the Russian Federation, Civil, Tax, Administrative and Criminal Codes, Federal Law No. 125-FZ "On Freedom of Conscience and Religious Associations", as well as other laws and regulations of the Russian Federation and the subjects of the federation. The current Federal Law No. 125-FZ "On Freedom of Conscience and Religious Associations" was adopted in 1997 as a result of many years of work on several variants of draft laws. To date, it has been subjected to repeated editions, which reflect the dynamics of the contemporary model of state-religious relations.

The procedure for the registration and functioning of religious organizations is regulated by Federal Law No. 125-FZ "On Freedom of Conscience and Religious Associations" of Sept. 26, 1997, which classifies religious associations into religious groups and religious organizations. A religious association in the Russian Federation is defined as "a voluntary association of citizens of the Russian Federation and other persons permanently and legally residing on the territory of the Russian Federation, which is organized for the purpose of joint confession and spread of faith and has the features that appropriate for this purpose: confession; officiation; other religious rites and ceremonies; religious education of the followers" [10].

In accordance with Article 8 of Federal Law No. 125 "religious organization is a voluntary association of citizens of the Russian Federation and other persons permanently and legally residing in the territory of the Russian Federation, established as a religious organization for the purpose of joint confession and dissemination of faith, and registered as a legal entity in the manner prescribed by law". Depending on the territorial scope religious organizations are subdivided into centralized and local. State registration of centralized organizations that have local religious organizations in the territory of two or more constituent entities of the Russian Federation is ordered by a decision of central bodies of The Ministry of Justice of Russia. Local bodies of The Ministry of Justice of the Russian Federation register local religious organizations, centralized religious associations that have local religious organizations in the territory of one constituent entity of the Russian Federation, religious organizations (including institutions) established by these centralized religious associations. A local religious organization consists of not less than ten participants who have reached the age of eighteen years and who permanently reside in one locality or in one urban or rural settlement. According to Article 11 of Federal Law No. 125 , local religious organizations can be established by a group of ten adult Russian citizens living in one locality or settlement, by a centralized religious association, or on the basis of the acknowledgment issued by such organization. Previously, under Article 11, paragraph 5, for establishment of a local religious organizations it was necessary to provide information confirming either entering into a centralized religious organization or activities, 
carried out in the given territory for at least fifteen years. As a result, many such communities were registered as members of a centralized religious association. At present, this requirement is excluded [11]. After amending Federal Law No. 125, we can expect both a decrease in the number of centralized religious organizations and an increase in the number of independent local communities.

According to The Federal State Statistics Service, by April 2019269 Buddhist religious organizations were registered on the territory of the Russian Federation [12]. It should be noted that the state statistics do not differentiate Buddhist religious organizations according to different trends and schools, all of them are included in the general category of "Buddhism", unlike, for example a clearer distinction between Christian churches and denominations.

Table 1. Number of Buddhist Religious Organizations in Russia [12].

\begin{tabular}{|l|c|c|c|c|c|}
\hline \multirow{2}{*}{ Year } & Total & $\begin{array}{c}\text { Centralized } \\
\text { Religious } \\
\text { Organizati } \\
\text { on }\end{array}$ & $\begin{array}{c}\text { Local } \\
\text { Religious } \\
\text { Organizati } \\
\text { ons }\end{array}$ & $\begin{array}{c}\text { Spiritual } \\
\text { educationa } \\
\text { I } \\
\text { institutions }\end{array}$ & $\begin{array}{c}\text { Monasteri } \\
\text { es }\end{array}$ \\
\hline $\mathbf{2 0 0 3}$ & 218 & 11 & 205 & 2 & \\
\hline $\mathbf{2 0 0 4}$ & 192 & 10 & 180 & 2 & \\
\hline $\mathbf{2 0 0 6}$ & 197 & 10 & 184 & 2 & 1 \\
\hline $\mathbf{2 0 0 8}$ & 200 & 9 & 188 & 2 & 1 \\
\hline $\mathbf{2 0 0 9}$ & 198 & 5 & 191 & 2 & \\
\hline $\mathbf{2 0 1 0}$ & 208 & 9 & 196 & 3 & \\
\hline $\mathbf{2 0 1 1}$ & 217 & 11 & 203 & 3 & \\
\hline $\mathbf{2 0 1 3}$ & 230 & 10 & 218 & 2 & \\
\hline $\mathbf{2 0 1 4}$ & 241 & 11 & 228 & 2 & \\
\hline $\mathbf{2 0 1 5}$ & 246 & 11 & 233 & 2 & \\
\hline $\mathbf{2 0 1 6}$ & 252 & 11 & 239 & 2 & \\
\hline $\mathbf{2 0 1 7}$ & 259 & 12 & 245 & 2 & \\
\hline $\mathbf{2 0 1 8}$ & 265 & 12 & 251 & 2 & \\
\hline $\mathbf{2 0 1 9}$ & 269 & 12 & 254 & 2 & \\
\hline & & & & & \\
\hline
\end{tabular}

We should separately emphasize the problem of interacting and correlating the groups and organizations of the followers of "traditional" and "non-traditional" Buddhism in Buryatia. There are several historically relatively independent hierarchical systems in Buddhism integrated into centralized religious organization. According to the Vinaya, the Tantra and Bodhisattva vows in Buddhism, including the Gelug school, "three types of communities are constituted: Sangha Monks, Ganachakra Tantrists and the community of laity, not practicing Tantric methods". A number of researchers studying "modern", "globalized", "transnational" Buddhism in Russia note its significant difference from traditional institutions of Buddhism, the impermanence of community members and secular character. In 
contemporary Russia, there is a variety of ways in which Buddhist groups engage with tradition, which can generally be grouped into two clusters. The first one postulates "tradition" as an important attribute of Russian Buddhism in regions that are called "traditionally Buddhist" (Buryatia, Kalmykia and Tuva). Here, the increased presence of Buddhism in the post-socialist period is referred to as a "revival" of "traditional" forms. It also plays a role beyond the religious sphere, as Buddhism there is also an important component of the national identity. However, in these regions, there are noticeable differences in the ways that "tradition" is understood, and the ways in which its influence on the present is envisioned. The second way of engaging with tradition is through reforming it. This tendency is present in new Buddhist communities in Russian cities. They are influenced by "Western" educational, religious and political institutions, and often bundle around the Tibetan diaspora. Many researchers and publicists postulate the institutionalization of regional forms of Buddhism as traditionalist ethnic in Buryatia, Kalmykia and Tyva, and extra-ethnic globalized, primarily in large cities. At the same time, legal registration procedure doesn't provide any significant differences between these types of Buddhist communities.

In addition, it is important to study the political role of the Buddhist community in ethnopolitical processes in the Russian regions, because historically it had ethnoconsolidating functions, which in other countries the government assumed. Therefore, the influence of Buddhism on the formation of national awareness, national ideology of the Buryats, the Kalmyks and the Tuvans was more significant, than in countries with strong national statehood. The issues related to the potential of the Buddhist factor in RussianMongolian relations also play an important role.

\section{Conclusion}

Post-Soviet development of Russia within the confines of democratic political system and civil society institutions for the last twenty years, freedom of conscience, lack of state ideology, and shifts in socio-economic structure significantly changed the position of Buddhist religion. Buddhism's development in Russia is interpreted ambiguously in the public information space, scientific literature and public opinion. This process affects all aspects of social life: it has socio-cultural, political and economic content and takes place both at the institutionalized level of religious organizations and in everyday practices of social interaction.

We can state a significant increase in the number of believers and religious organizations, the penetration of Buddhist ideas and values into the mass culture and public information space. At the same time, it is particularly relevant to identify the peculiarities of institutionalization of Buddhist culture in the new social, economic and political conditions, which are characterized by the predominance of urban population, changes in the way of life, formation of a modern democratic system and new international political conditions.

At present, there are different forms of Buddhist communities in Russia, reproducing a variety of historical and cultural traditions, their organizational principles, which distinction is of great importance for researchers, state bodies and believers. Among the factors influencing the diversity of Buddhist communities, it is necessary to emphasize state policy and legal regulation that unifies the forms of their activity, so that "at the present time several organizations are established in a unified form of religious associations, but, from a civilized standpoint, they have fundamental differences in the internal structure and governing principles etc." [13]. At the same time, the development of Buddhist communities is significantly influenced by institutional historical, cultural and doctrinal 
factors, all this result in formation of different types of communities and variety of their social practices.

The paper was prepared with the financial support of the Russian Foundation for Basic Research, grant 20-011-00531 "Russian Buddhism and Social Media: Digital Transformation of Buddhist Communities"

\section{References}

1. Zh.T. Toschenko, The State as a Subject of Theocracy, 2, 2-27 (2007)

2. J. Burbank, An Imperial Rights Regime: Law and Citizenship in the Russian Empire, 7.3, 397-431 (2006)

3. N.V. Tsyrempilov, Buddhism and the Empire. Buryat Buddhist Community in Russia $\left(18^{\text {th }}\right.$ - the beginning of the $20^{\text {th }}$ century) (IMBT SB RAS Publ., Ulan-Ude, 2013)

4. V.B. Tsybikzhapov, Problems of Overcoming the Vestiges of Lamaism, Shamanism and Old Belief. Contemporary Monastic Organization of Lamaism in Buryatia (Buryat book Publ., Ulan-Ude 1971)

5. Lamaism in Buryatia of the $18^{\text {th }}$ - the early $20^{\text {th }}$ century. The Structure and Social Role of Cults (Nauka Publ., Novosibirsk, 1983)

6. T.B. Badmatsyrenov, Buddhist Clergy as a Specific Socio-Professional Group (a case study of the Republic of Buryatia) (Buryat State University Publ., Ulan-Ude, 2012)

7. K.M. Gerasimova, Lamaism and Colonial National Policy of Tsarism in Transbaikal in the $19^{\text {th }}$ - early $20^{\text {th }}$ centuries (Buryat book Publ., Ulan- Ude, 1957)

8. N.V. Tsyrempilov, The State, Religion, Church in Russia and Abroad. Constitutional Theocracy of Lubsan-Samdan Tydenov: An Attempt to Create a Buddhist state in Transbaikal (1918-1922) 4 (33), 318-346 (2015)

9. E.S. Safronova, Buddhism in Russia (Russian Academy of Public Administration Publ., Moscow, 1998)

10. On Freedom of Conscience and Religious Associations. Federal Law No. 125-FZ of September 26, 1997 (as amended on March 30, 2016)

11. On Amending Federal Law "On Freedom of Conscience and Religious Associations" (Federal Law No. 261-FZ of July 13, 2015)

12. The Number of Religious Organizations Registered in the Russian Federation as of January 1, 2019 (2019) Available at:

http://www.gks.ru/wps/wcm/connect/rosstat_main/rosstat/ru/statistics/state/\#

13. T.V. Soifer, Journal of Russian Law. Toward the Legal Status of Non-Profit Organizations, 1, 27-35 (2009) 